\title{
Medical Gases Cylinder Risk Evaluation To Prevent Risk
}

\author{
$\operatorname{Ivan}^{1}$
}

${ }^{1}$ Student of Information Technology, Swiss German University, Tangerang 15143, Indonesia

\section{Article Information}

Received:

Accepted:

Published:

DOI:

\section{Corresponding Author:}

Ivan Ivan

Email:

leonhardivan@gmail.com

ISSN $\quad 2355-1771$

\begin{abstract}
Medical gases for medical treatment, are used to give gas therapy to the patient. They are widely used in hospitals, clinics, dental clinics, homes, and other healthcare facilities. They are essential and request zero faults. Because of the impact of medical gases fault, may could someone injury or even death. The incidents of using medical gases are still founding in several countries, including Indonesia. This research paper was conducted to give a perspective of risk evaluation, so medical gases cylinder management could get attention. Normally the incidents in using medical gases are caused by human error and fraud. Human error in using medical gases could make somebody death, and fraud could make financially lost which could affect operational cost. The explanation will be shown on the risk heat map and also the risk scorecard. This is facilitating to make it easier to take a decision for the priority of risk that should be mitigated or manage.
\end{abstract}

Keywords: medical, gases, risk, management, hospital, engineer, instalasi, gas, medis.

\section{Introduction}

The hospital is required zero faults in their operations. Therefore they need a good standard operational procedure and good risk management to prevent accidents. Safety of using medical gases cylinder should be triaged, considering medical gases as one of the main facilities at the hospital, so medical gases should have reliability when in use. Because a fault of using medical gases could make a serious injury or death. The safety of using medical gases must fulfill four safety principles: identity, adequacy, continuity of supply, and quality of supply.[1] Because of that safety principles, the hospital should train the human resources related to managing, distributing and maintaining the medical gases. A standard operating procedure based on ISO 31000: 2018 should be review and implementing it into the organization. This is to prevent the incident. [2] Sometimes when exchanging medical gases cylinders, the labeling and verifying which give the information for the contents is lack attention. The wrong medical gases cylinder contents supply could cause death incident. Since the fastest and accurate model to confirm the medical gases cylinder content is by reading the label, so it is an important notice to read it carefully. Although the medical gases cylinder has a different type of connector for each variety of gases. [3] To prevent dispensed the wrong gas to the patient, the important thing is to do cross-connection test. This test should be done by the contractor who is an expert on the medical gas pipeline system or authorized person. Cross-connection test is needed when we install the new pipeline system and also when change or modified existing system This is to meet the general safety of using medical gases, which is quality of supply.[1] The incident of using medical gases and also the risk causes with impact could give a picture of what frequently happens on using of medical gases. Like in table 1. 
Table 1. Data of risk causes, risk impact and risk element.

\begin{tabular}{|c|c|c|c|c|c|}
\hline No. & Citation & $\begin{array}{l}\text { Risk causes } \\
\end{array}$ & Risk Impact & Risk Element & Category \\
\hline 1. & $\begin{array}{l}\text { Bankstown-Lidcombe } \\
\text { Hospital in June and July } \\
\text { 2016: dispensing incorrect } \\
\text { gas to two neonates through } \\
\text { a neonatal resuscitaire in } \\
\text { Operating Theatre 8. } \\
\text { [4] }\end{array}$ & $\begin{array}{l}\text { The incorrect installation } \\
\text { of the pipes and } \\
\text { subsequent flawed testing } \\
\text { and commissioning } \\
\text { process, which should } \\
\text { have detected the } \\
\text { installation error. }\end{array}$ & $\begin{array}{l}2 \text { Babies death } \\
\text { because of inhale } \\
\text { nitrous oxide } \\
\text { instead of oxygen, } \\
\text { it's prevented } \\
\text { effective } \\
\text { resuscitations }\end{array}$ & $\begin{array}{l}\text { - Human Error } \\
\text { - Standard Operating } \\
\text { Procedure not } \\
\text { applied }\end{array}$ & Human Error \\
\hline 2. & $\begin{array}{c}2 \text { people died in Bengkulu } \\
\text { hospital when inhale } \\
\text { wrong medical gases } \\
\text { supply, they inhale CO2 } \\
\text { instead of N2O } \\
\text { [5] }\end{array}$ & Wrong gas supply. & $\begin{array}{c}2 \text { peoples death } \\
\text { because of inhale } \\
\text { Carbon Dioxide } \\
\text { instead of Nitrous } \\
\text { Oxide, during the } \\
\text { surgery }\end{array}$ & $\begin{array}{l}\text { - Human Error } \\
\text { - No control of using } \\
\text { medical gases }\end{array}$ & Human Error \\
\hline 3. & $\begin{array}{l}\text { A hospital wanted to } \\
\text { modify its existing gas } \\
\text { supply for an expansion } \\
\text { project. The modification } \\
\text { was to move existing } \\
\text { piping due to civil works } \\
\text { (by another contractor) } \\
\text { and to add connections to } \\
\text { supply gases to } 8 \text { delivery } \\
\text { rooms and an operating } \\
\text { theatre. } \\
\text { After several cancellations, } \\
\text { work was scheduled by the } \\
\text { hospital for a Friday. A } \\
\text { Gas Company's } \\
\text { engineering representative } \\
\text { and contractor were to } \\
\text { attend site to move the gas } \\
\text { piping at the same time as } \\
\text { other tradesmen working } \\
\text { on other impacted services. } \\
\text { At the last minute, the } \\
\text { hospital changed the } \\
\text { schedule to Saturday. The } \\
\text { engineering representative } \\
\text { could not be on site on } \\
\text { Saturday but the contractor } \\
\text { based on his qualification } \\
\text { was instructed to complete } \\
\text { the work without } \\
\text { supervision. } \\
\text { Work was completed on } \\
\text { the Saturday. } \\
\text { When performing pre- } \\
\text { startup checks in the }\end{array}$ & $\begin{array}{l}\text { The modification was to } \\
\text { move existing piping due } \\
\text { to civil works (by } \\
\text { another contractor) and } \\
\text { to add connections to } \\
\text { supply gases to } 8 \\
\text { delivery rooms and an } \\
\text { operating theatre, without } \\
\text { engineering } \\
\text { representative. }\end{array}$ & $\begin{array}{l}\text { When performing } \\
\text { pre-startup checks } \\
\text { in the operating } \\
\text { theatres on } \\
\text { Monday, the } \\
\text { anaesthetist's } \\
\text { stations started to } \\
\text { alarm indicating } \\
\text { low oxygen level in } \\
\text { supplied gas. }\end{array}$ & $\begin{array}{l}\text { - Human Error } \\
\text { - Standard Operating } \\
\text { Procedure not } \\
\text { applied }\end{array}$ & Human Error \\
\hline
\end{tabular}




\begin{tabular}{|c|c|c|c|c|c|}
\hline & $\begin{array}{l}\text { operating theatres on } \\
\text { Monday, the anaesthetist's } \\
\text { stations started to alarm } \\
\text { indicating low oxygen } \\
\text { level in supplied gas. } \\
\text { No patients were involved. } \\
{[6]}\end{array}$ & & & & \\
\hline 4. & & $\begin{array}{l}\text { Authorised person at } \\
\text { hospital return full } \\
\text { cylinder to supplier }\end{array}$ & Financial lost & $\begin{array}{l}\text { - Fraud } \\
\text { - No control of using } \\
\text { medical gases }\end{array}$ & Fraud \\
\hline 5. & $\begin{array}{l}\text { A simple mistake in the } \\
\text { labelling and identification } \\
\text { of medical gas lines } \\
\text { resulted in a cross- } \\
\text { connection of the oxygen } \\
\text { and air, causing } \\
\text { perioperative hypoxemia } \\
\text { following } \\
\text { administration of a mixture } \\
\text { poor in oxygen. } \\
\text { [7] }\end{array}$ & $\begin{array}{l}\text { Wrong medical gases } \\
\text { pipeline system labeling. }\end{array}$ & $\begin{array}{c}2 \text { people } \\
\text { hypoxemia. }\end{array}$ & $\begin{array}{l}\text { - Human Error } \\
\text { - No periodic testing } \\
\text { or verification. }\end{array}$ & Human Error \\
\hline 6. & $\begin{array}{l}3 \text { Copper tube reporting } \\
\text { lost in hospital, but no } \\
\text { body knows when the } \\
\text { pipeline was gone } \\
{[8]}\end{array}$ & $\begin{array}{l}3 \text { copper tube was } \\
\text { disappear }\end{array}$ & Financial lost & $\begin{array}{l}\text { - Fraud } \\
\text { - Human error } \\
\text { - No assets control }\end{array}$ & Fraud \\
\hline 7. & $\begin{array}{c}\text { Run out of oxygen gases } \\
\text { while doing surgery. } \\
\text { [9] }\end{array}$ & Run out of medical gases & $\begin{array}{l}\text { Patient hardly to } \\
\text { breathe }\end{array}$ & $\begin{array}{l}\text { - Human error } \\
\text { - Standard Operating } \\
\text { Procedure not } \\
\text { applied }\end{array}$ & Human Error \\
\hline 8. & $\begin{array}{l}\text { RESEARCH } \\
\text { NOVELTY }\end{array}$ & $\begin{array}{l}\text { - Cross connection } \\
\text { - Wrong medical gases } \\
\text { supply } \\
\text { - Fraud } \\
\text { - Run out of medical } \\
\text { gases }\end{array}$ & $\begin{array}{l}\text { Risk impact could } \\
\text { be cause somebody } \\
\text { injury, or even } \\
\text { death, financial lost } \\
\text { and bad reputation. }\end{array}$ & $\begin{array}{l}\text { - Fraud } \\
\text { - Human error } \\
\text { - Standard Operating } \\
\text { procedure not } \\
\text { applied } \\
\text { - No periodic testing } \\
\text { and inspection }\end{array}$ & $\begin{array}{l}\text { - Risk profile } \\
\text { - Risk } \\
\text { Analysis } \\
\text { - Risk } \\
\text { Assessment } \\
\text { - Operation } \\
\text { risk }\end{array}$ \\
\hline
\end{tabular}

This research paper's novelty is conducted to explain the fraud and human error has an impact on hospital reputation and financial (Table 1). Normally the risk happens in the organization or internal of the hospital. The medium level risk of fraud and high-level risk of human error is to determine the decision to minimized the gap between the high-level management and the operation. The following gap is :

1. Fraud because there is no surveillance of using medical gases. 
2. Human error because of no training.

3. Standard Operating procedure not applied because of no knowlegde about medical gases risk impact. (No safety training)

4. No periodic testing and inspection.

\section{Methods}

A case study could be used to define incidents, testing theory, and make a new theory. [10] The case study methodology is based on qualitative analysis and focuses on observation of a social phenomenon, individual, organization, group, or institution. This method could see deep and analyze the incident and their causes factor. This method also could determine the process of some incidents. The investigation of the risk factor and risk element could make a good risk analysis. [11] The research method will be observation and collecting data, several accidents report will be analyzed.

Risk Evaluation (Figure 1), when risk scenarios are analyzing, two elements should be assessed, probability, and the risk impact. [12] Scorecard and heat map is used in the risk assessment process, by the risk assessment the organization will be aware of the risk causes and risk impact. The outcome will be risk mitigation of using medical gases at the hospital.[13]

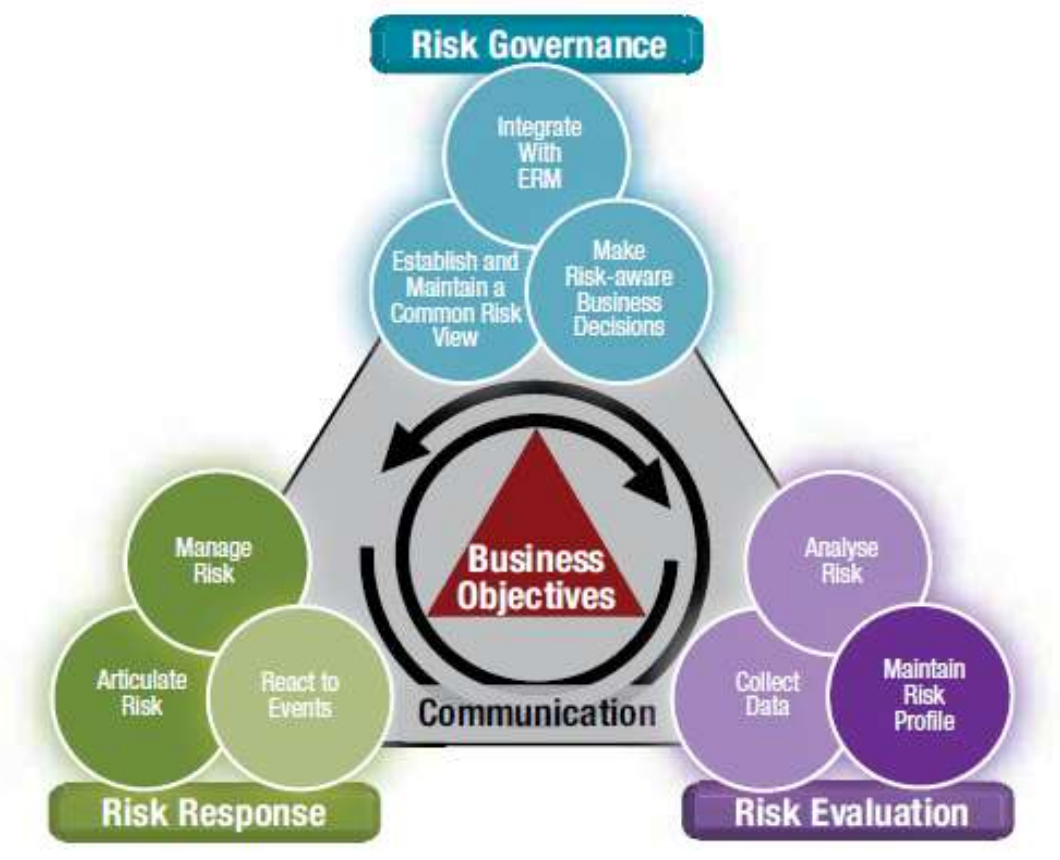

Figure 1. Key risk indicators and risk reporting [12]

This research paper was conducted using Strategic Uncertainty Assessment Scorecard for Exposure, based on incidents that happen. It will be a focus on the Business/Operational and financial category of that table, to determine risk assessment. Risk analysis will be achieved with a risk heat map and calculation. [14] Visual scorecard to give us a perspective about risk probability and Risk Impact, and the result as a heatmap is made focus on a risk that should be prioritized. After prioritizing a risk, the solution will be risk management, at this step the risk will be mitigated. 
Table 2. Strategic Uncertainty Assessment Scorecard for Exposure [13]

\begin{tabular}{ccccccccccccc}
\hline Categories of Strategic Uncertainity & \multicolumn{4}{c}{ Exposure } & \multicolumn{4}{c}{ Likelihood } \\
\hline & Low & & & High & Low & & & High \\
\hline Business/Operational & 1 & 2 & 3 & 4 & 5 & & 1 & 2 & 3 & 4 & 5 \\
Financial & 1 & 2 & 3 & 4 & 5 & & 1 & 2 & 3 & 4 & 5 \\
Market Conditions & 1 & 2 & 3 & 4 & 5 & & 1 & 2 & 3 & 4 & 5 \\
Technology & 1 & 2 & 3 & 4 & 5 & & 1 & 2 & 3 & 4 & 5 \\
Business Relationships & 1 & 2 & 3 & 4 & 5 & & 1 & 2 & 3 & 4 & 5 \\
Policy \& Regulation & 1 & 2 & 3 & 4 & 5 & & 1 & 2 & 3 & 4 & 5 \\
\hline
\end{tabular}

Risk analysis using a scorecard, change qualitative data to quantitative data. A scorecard is needed to assess the risk and could give input for planning activity and risk mitigation. Table 1 case study rated by using table 2 risk assessment scale 1 to 3,1 is low or no effect for the process and 3 is for high and important and has an impact for the process. [13] This risk assessment guides the organization to scale the priority of the risk which should be immediately taking action, and also a decision for the risk control, mitigate, transfer, avoid or accept. Heat map results could be used to determine risk assessment (Table 2). Risk assessment could do by 5 X 5 heat map design. The vertical axis shows the probability of risk. The horizontal axis shows the risk impact. The risk result could be obtained by the formula below[15]

\section{Risk $=$ Risk Potential impact $\mathrm{X}$ Probability of risk}

Table 2. Heat map of potential risk analysis.[15]

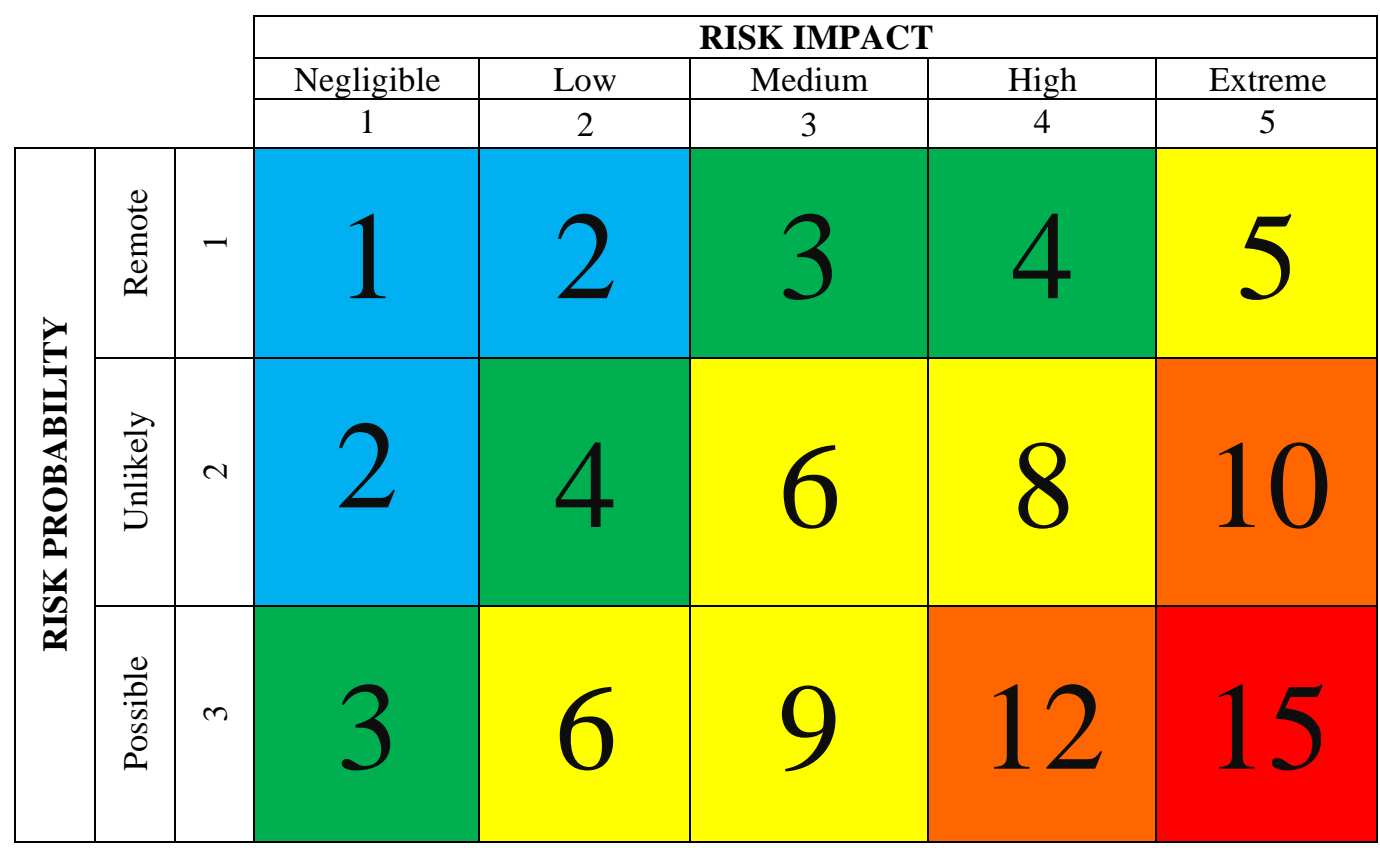




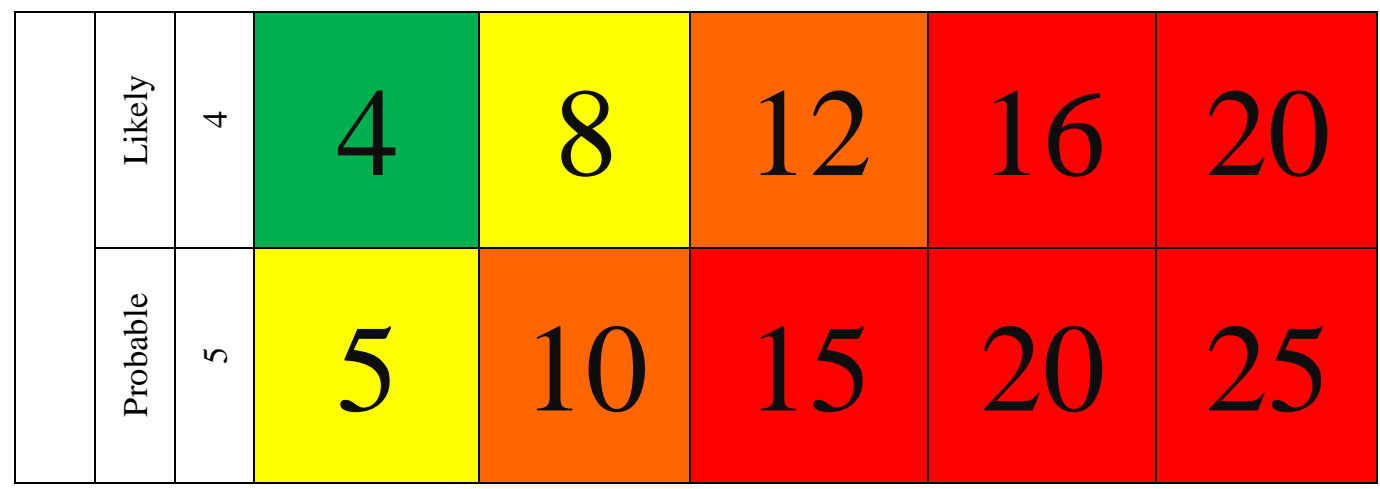

The risk causes with the risk impact and risk probability could give a picture of what frequently happens on using of medical gases. This risk analysis could make a risk awareness and guidance to plan and organize risk. Risk analysis shows the risk causes normally because of human factors, no control of using medical gases, Standard operating procedure not applied, and fraud. This risk assessment with a scorecard and heat map could determine the risk which is important to be mitigated. Table 4 define Red color is a very high risk, orange color is for high risk and need to take an action immediately, a yellow color is for medium risk and need to find a solution to prevent the risk, green color is for low risk, Blue Colour is for no effect or acceptable. For example, if the risk does not cause death and not important it should be in a blue position.[14],[12]

Table 3. Risk Assessment.

\begin{tabular}{|c|l|}
\hline VERY HIGH & $\begin{array}{l}\text { Score 15-25, This is a very high impact with high probable to be happens, } \\
\text { and should takes immediate action, how to mitigate or avoided the risk. } \\
\text { Because it could be affected the business process and financial lost. }\end{array}$ \\
\hline HIGH & $\begin{array}{l}\text { Score 10-12, This is a high impact with likely to be happens, and should } \\
\text { takes an action, how to mitigate the risk. Because it could be affected the } \\
\text { business process and financial threats. }\end{array}$ \\
\hline MEDIUM & $\begin{array}{l}\text { Score 5-9, This is a medium impact with possible to be happens and } \\
\text { should takes a plan to take an action with a reasonable time. Because it } \\
\text { could be affected the business process and safety but not necessary. }\end{array}$ \\
\hline LOW & $\begin{array}{l}\text { Score 3-4, This is a low impact with chance of incident could be happens } \\
\text { is unlikely. Because it almost no effect for the business process and } \\
\text { financial. }\end{array}$ \\
\hline VERY LOW & $\begin{array}{l}\text { Score 1-2, This is a very low impact with chance of incident could be } \\
\text { happens is remote. Because it is no effect for the business process, and } \\
\text { financial, but it could be accept or tolerance. }\end{array}$ \\
\hline
\end{tabular}

Results and discussion

Table 4. Risk Probability Score

\begin{tabular}{|c|l|c|c|c|c|}
\hline No. & Risk Category & $\begin{array}{c}\text { Total number } \\
\text { of favourable } \\
\text { outcomes } \\
\mathbf{n}(\mathbf{A})\end{array}$ & $\begin{array}{c}\text { Number of } \\
\text { favourable } \\
\text { outcome } \\
\mathbf{n}(\mathbf{S})\end{array}$ & $\begin{array}{c}\text { Risk Probability } \\
\mathbf{n}(\mathbf{A}) / \mathbf{n}(\mathbf{S})\end{array}$ & $\begin{array}{c}\text { Risk Probability } \\
\text { in Percentage }\end{array}$ \\
\hline 1. & Human Error & 6 & 6 & 1 & $100 \%$ \\
\hline 2. & Fraud & 4 & 2 & 0,5 & $50 \%$ \\
\hline
\end{tabular}

Four types of medical gases normally using at a hospital is Oxygen, N2O, Air, and Vacuum, the total number of favorable outcomes is 6 because oxygen has a probability of changing with $\mathrm{N} 2 \mathrm{O}$, Air, and Vacuum, and N2O has a probability of changing with air and vacuum, the last one is air is possible to change with the vacuum. So there is 6 times the potential to cross-connection between 
the gases caused by human error, there are also 6 possibilities. For the fraud, there are four types of medical gases, but the potential to do the fraud is 2 types of medical gases because normally compressed air and vacuum using an automatic machine, not a cylinder.

Table 5. Risk Probability Assessment.

\begin{tabular}{|c|c|c|}
\hline PROBABLE & $>90 \%-100 \%$ & 5 \\
\hline LIKELY & $>50 \%-90 \%$ & 4 \\
\hline POSSIBLE & $>25 \%-50 \%$ & 3 \\
\hline UNLIKELY & $>10 \%-25 \%$ & 2 \\
\hline REMOTE & $0 \%-10 \%$ & 1 \\
\hline
\end{tabular}

Risk probability assessment is to define the risk probability score. $0 \%-10 \%$ score is one or the event probability is remote. More than $10 \%$ to $25 \%$ score is 2 or the event probability is unlikely. More than $25 \%$ to $50 \%$ score is 3 or the event is possible. More than $50 \%$ to $90 \%$ score is 4 or the event is likely. More than $90 \%$ to $100 \%$ score is 5 or the event is probable.

Table 6. Risk Impact Score

\begin{tabular}{|c|c|c|c|}
\hline No. & Risk Category & Risk Impact & Risk Impact Score \\
\hline \multirow{5}{*}{1.} & \multirow{5}{*}{ Human Error } & No Effect & 1 \\
\hline & & Wound & 2 \\
\hline & & Injury & 3 \\
\hline & & Permanent Disability & 4 \\
\hline & & Death & 5 \\
\hline \multirow{5}{*}{2.} & \multirow{5}{*}{ Fraud } & < Rp. $10.000 .000 /$ year & 1 \\
\hline & & > Rp. $10.000 .000-$ Rp. $50.000 .000 /$ year & 2 \\
\hline & & > Rp. 50.000.000 / tahun - Rp. 100.000 .000 / year & 3 \\
\hline & & $>$ Rp. 100.000.000/tahun - Rp. 200.000.000 / year & 4 \\
\hline & & > Rp. 200.000 .000 / year & 5 \\
\hline
\end{tabular}

The risk impact for human error has a score of 5 or very high level, if the impact is has possibility to make somebody death. The risk impact for the fraud category, if cause financial lost Rp. 100.000.000 and up per year it could be categorized at score 3 or medium level. For the human error category, if cross-connection or wrong gases supplied happens, it could be caused somebody death, and it could damage the hospital reputation.

Table 7. Risk assessment result

\begin{tabular}{|c|l|c|c|}
\hline No. & \multicolumn{1}{|c|}{ Category } & Risk Impact & Risk Probability \\
\hline 1. & Human Error (Business / Operational) & 5 & 5 \\
\hline 2. & Fraud (Financial) & 2 & 3 \\
\hline
\end{tabular}

Table 7 results would explain to the heat map, which is made easier to read. For example for the human error risk category, the risk impact is 5 or very high, because it could make somebody death, and the risk probability score is 1 or also probable. So the risk will be on a high level of risk. Herewith the explanation about how the impact and probability were scored. For the fraud, 200 beds of a hospital normally using around 800 cylinders per month for oxygen and 4 cylinders for $\mathrm{N} 2 \mathrm{O}$. So the financial loss per year is around Rp. 31.200.000 - Rp. 40.000 .000 per year or even more. This sample and interview get from type $\mathrm{C}$ hospital. 


\section{Conclusion}

We should decide on the risk priority, to focus on the important problem. After decided the risk priority scale, started to make a plan, running the program, analyzing, monitoring, and evaluating. After that risk assessment is needed to determine the next step to preventing the risk. So control, monitoring, and evaluation will be applied for the higher risk that could happen. Risk management is needed to make a security program. This is key to success protection. So this is should be a management function of some organization or procedure because the risk cannot omit, but it could be mitigated.[14] This research paper's novelty is found the fraud and human error have an impact on the hospital's reputation and financial shown by the level of risk. Fraud could affect the operational cost will be high, at the end could affect the price charge to the patient will be high also. To mitigate the risk of fraud and human error the author suggests using IT-based system control using the application.

\section{References}

[1] Great Britain and Department of Health, Medical gases: health technical memorandum 02-01: medical gas pipeline systems. London: Stationery Office, 2006.

[2] T. Y. Aldyth and S. D. Ede, "Evaluation of Risk Management Implementation in Medical Gas Installation Hospitals with ISO 31000: 2018 Approach," Aug. 08, 2019. https://doi.org/10.26911/theicph.2019.04.03 (accessed Oct. 03, 2020).

[3] J. R. Hart, “Medical Gas and Vacuum Systems Installation Handbook," 2015. https://b-ok.asia/ireader/2885311 (accessed Oct. 04, 2020).

[4] Chief Health Officer, "Bankstown - Lidcombe Hospital Medical Gases Incident : Final Report," p. 24, Aug. 2016, doi: https://www.health.nsw.gov.au/Hospitals/Documents/bankstown-lidcombe-incident-final-report.pdf.

[5] "Dokter Dianggap Lalai, Dua Nyawa Melayang - News Liputan6.com."

https://www.liputan6.com/news/read/28945/dokter-dianggap-lalai-dua-nyawa-melayang (accessed Nov. 08, 2020).

[6] "EIGA TP 40_14_Recent_Incidents_SAC138.pdf." Accessed: Oct. 03, 2020. [Online]. Available: http://www.bcga.co.uk/assets/EIGA\%20TP_40_14_Recent_Incidents_SAC138.pdf.

[7] M. Dangoisse, M. Lalot, and J. Lechat, "Connection error in the delivery of medical gases to a surgical unit," Acta anaesthesiologica Belgica, vol. 61, pp. 33-7, Mar. 2010.

[8] “Pipa Instalasi Gas Medis RSUD TP Dilaporkan Hilang." https://anteroaceh.com/news/pipa-instalasi-gas-medis-rsud-tpdilaporkan-hilang/index.html (accessed Nov. 08, 2020).

[9] K. C. Media, "Oksigen Habis Saat Operasi Pasien, Ini Penjelasan Dokter," KOMPAS.com. https://regional.kompas.com/read/2015/08/15/09512711/Oksigen.Habis.Saat.Operasi.Pasien.Ini.Penjelasan.Dokter (accessed Nov. 08, 2020).

[10] Eisenhardt, Kathleen M. Building Theories From Case Study Research. Academy of Management. The Academy of Management Review; Oct 1989; 14, 4; ABI/INFORM Global. pg. 532.

[11] "Kothari_-_Research_Methodology_Methods_and_Techniques_-_2004.pdf." Accessed: Oct. 22, 2020. [Online]. Available: https://dinus.ac.id/repository/docs/ajar/Kothari_-_Research_Methodology_Methods_and_Techniques_-_2004.pdf.

[12] Risk it practitioner guide. Place of publication not identified: Isaca, 2009.

[13] A. Gray, J. Detre, B. Briggeman, and M. Boehlje, "Scorecarding and Heat Mapping: Tools and Concepts for Assessing Strategic Uncertainty," International Food and Agribusiness Management Review, vol. 09, Feb. 2006.

[14] P. Bowen, J. Hash, and M. Wilson, “Information Security Handbook: A Guide for Managers," p. 178, Oktober 2020.

[15] "communicate-risks-using-heat-map.pdf." Accessed: Oct. 29, 2020. [Online]. Available:

https://web.actuaries.ie/sites/default/files/erm-resources/communicate-risks-using-heat-map.pdf. 